\title{
PENINGKATAN KREATIVITAS ANAK USIA DINI MELALUI CERITA BERGAMBAR DI SEKOLAH DASAR ZAHA (ZAINUL HASAN)
}

\author{
Beny Hamdani ${ }^{1}$ \\ ${ }^{1}$ Universitas Islam Zainul Hasan Genggong Probolinggo \\ e-mail: benyhamdani.ielts9.consultation@gmail.com
}

Received : May 28, 2020

Revised : May 31

Accepted : June 3, 2020

\begin{abstract}
ABSTRAK
Studi ini memaparkan tentang peningkatan kreatifitas anak usia dini melalui cerita bergambar di sekolah dasar Zainul Hasan genggong Probolinggo. Rumusan masalah yakni (1) bagaimana penerpaan cerita bergambar dalam meningkatkan kreatifitas anak di Sekolah Dasar Zainul Hasan Genggong Probolinggo, (2) Apa saja faktor pendukung dan penghambat kreatifitas anak usia dini di sekolah dasar Zainul Hasan Genggong Probolinggo. Manfaat yang diharapkan dari penelitian ini untuk menambah wawaan bagi guru-guru anak usia dini menjaidi guru yang prosefisonal dan berkompeten dibidangnya dan meningkatkan mutu pembelajaran di kelas. Metode penelitian menggunakan pendekatan kualitatif yang mana datana diperoleh melalui metode observasi, wawancara dan dokumentasi. Dari hasil penelitian ini ditemukan bahwa penerapan metode cerita bergambar dapat meningkatkan kreativitas anak di sekolah dasar Zainul Hasan Genggong Probolinggo. Oleh karenanya, kepada guru untuk lebih mengoptimalkan kegiatan belajar mengajar dengan menggunakan media buku cerita bergambar yang menarik, menyenangkan dan bervariasi.

Kata Kunci: Anak Usia Dini, Kreatifitas, Cerita Bergambar.

\section{ABSTRACT}

This studi critically aims to describe the improvement of early childhood creativity through pictorial stories at the elementary school of Zainul Hasan Genggong Probolinggo. The formulations of the problem are (1) how the application of illustrated stories in engaging children's creativity at elemantary school of Zainul Hasan Genggong Probolinggo, (2) What are the supporting factors and inhibitors of early childhood creativity at the elemantary school of Zainul Hasan Genggong Probolinggo. The expected benefits of this study are to increase the scope for early childhood teachers to become prosefisonal and competent teachers in their fields and improve the quality of learning in the classroom. The research method uses a qualitative approach which is obtained through observation, interviews and documentation. From the results of this study, it was found that the application of the pictorial story method can enhance children's creativity in elementary schools Zainul Hasan Genggong Probolinggo. Therefore, the teacher is to optimize teaching and learning activities by using a picture book that is interesting, fun and varied.
\end{abstract}

Keywords: Early Childhood, Creativity, Picture Story. 


\section{PENDAHULUAN}

Pembelajaran sebagai media inti pendidikan mempunyai peran yang sagat penting dalam suksesi pendidikan agar mencapai tujuannya. Dalam undang-undang sisdiknas tahun 2006 menyatakan bahwa pendidikan nasional berfungsi mengembangkan kemampuan dan membentuk watak serta peradaban bangsa yang bermartabat dalam rangka mencerdaskan kehidupan bangsa, bertujuan untuk mengembnagkan potensi siswa agar menjadi manusia yang beriman dan bertaqwa kepada Tuhan Yang Maha Esa, berakhlak mulia, sehat, berilmu, cakap, kreatif, mandiri dan menjadi warga Negara demokrasi serta bertanggung jawab.

Mansur (2007:88) menyatakan bahwa pendidikan anak suia dini adalah suatu proses pembinaan tumbuh kembang anak usia lahir hingga enam tahun secara menyeluruh yang mencakup aspek fisik dan non fisik dengan memberikan rangsangan bagi perkembangan jasmani, rohani (moral dan spiritual), motorik, akal pikiran, emosional dan social yang tepat agar anak tumbuh dan berkembang secara optimal. Kemudian, Danar (2009:07) menyatakan bahwa pendidikan anak usia dini adalah upaya pembinaan yang ditujukan kepada anak sejak lahir sampai dengan usia enam tahun yang dilakukan melalui pemberian rangsangan pendidikan untuk membantu pertumbuhan dan perkembnagan jasmani dan rohani agar anak memiliki kesiapan memasuki pendidikan lebih lanjut.

Terdapat beberapa definisi mengenai anak usia dini. Definisi yang pertama, anak usia dini adalah anak yang berusia nol tahun atau sejak lahir sampai berusia kurang lebih delapan tahun (0-8). Sedangkan definisi yang kedua, menurut Undnag-Undang RI No. 20 Tahun 2003 Tentang system pendidikan nasional yang menyebutkan bahwa pendidikan anak usia dini adalah suatu upaya pembinaan yang ditujukan kepada anak sejak lahir sampai dengan usia enam tahun yang dilakukan melalui pemberian rangsangan pendiidikan untuk membantu pertumbuhan dan perkembnagan jasmani dan rohani agar anak memiliki kesiapan dalam memasuki pendidikan lebih lanjut. Dari pengertian tersebut dapat diratik kesimpulan bahwa anak usi adini adalah anak ayng berusia nol sampai 6 atau 8 tahun yang mengalami pertumbuhan dan perkembangan jasmani dan rohani.

Rachmawati (2010:13) menyatakan bahwa kreativitas adalah kemampuan seseorang untuk melahirkan sesuatu yang baru, baik berupa gagasan maupun karya nyata yang relative berbeda dengan apa yang telah ada, dan merupakan kemampuan berfikir tingkat tinggi yang mengimpilkasikan terjadinya eskalasi dalam kemampuan berpikir yang ditandai oleh sukses, diskontinuitas, diferensasi, integrasi antara setiap tahap perkembangan. 
Hurlock (1978:11) menyatakan bahwa cerita merupakan salah satu sarana untuk mengembangkan kreatifitas anak, karena dengan mendengarkan cerita imajinasi dan fantasi anak dapat terasah. Cerita bergambar merupakan sebuah kesatuan cerita disertai dengan gambargambar yang berfungsi sebagai penghias dan pendukung cerita yang dapat membantu proses pemahaman terhadap isi cerita tersebut.

Buku cerita disukai hampir semua anak apa lagi jika buku cerita tersebut berup ailustrasi bagus dengan sedikit permainan yang melibatkan mereka. Anak-naak akan merasa terlibat dalam petualangan dan konflik-konflik yang dialami karakter-karakter didalamnya, sehingga membaca pun akan semakin menyenangkan. Buku cerita menyediakan tempat bagi anak-anak untuk melepaskan diri dari permasalahan yang belum dapat terselesaikan.

Buku cerita bergambar dengan tema fantasi relialistis membantu anak berimajinasi tentang hal-hal yang berada diluar lingkungannya sehingga perkembangan pemikiran dan kreativitas anak tidak terbatas pada hal tertentu. Cerita fiksi membuat pembaca berimajinasi tentang sebuah karakter, pemandangan setting cerita, serta alasan terjadinya sebuah plot. Buku cerita non fiksi menstimulasi pembacanya bertanya-tanya sehubungan plot yang disajikan.

Pengalaman yang dialami anak usia dini berpengaruh kuat terhadap kehidupan selanjutnya. Pengalaman tersebut kakan bertahan lama bahkan tidak dapat terhapus hanya tertutupi, suatu saat bila ada stimulasi yang memancing pengalaman hidup yang pernah dialami maka efek tersebut akan muncul kembali dalam bentuk yang berbeda.

Berdasarkan pengamatan yang dilakukan, metode bercerita sudah diterapkan oleh guru dalam pembelajaran, namun beberapa anak masih memiliki daya kreativitas yang rendah. Hal ini dapat dilihat dari kegiatan anak sehari-hari yang mana masih menunggu guru, tidak mempunyai ide sendiri, belum bias mengungkapkan idenya sendiri kalau tidak dibantu oleh guru, anak-anak masih tergantung dengan guru. Permasalahan tersebut disebabkan karena guru tidak memaksimalkan media pembelajaran yang ada sehingga kegiatan bercerita kurang optimal.

\section{Rumusan Masalah}

Penelitian ini dapat dirumuskan masalah sebaai berikut: (1) Bagaimana penerapan cerita bergambar dalam meningkatkan kreativitas anak di sekolah dasar Zainul Hasan Genggong Probolinggo, (2) Apa saja faktor pendukung dan penghambat kreativitas anak usia dini di sekolah dasar Zainul Hasan Genggong Probolinggo?. Manfaat yang diharapkan dari penelitian ini adalah untuk menambah wawasan bagi guru-guru anak usia dini menjadi guru yang 
professional dan berkompeten dibidangnya sehingga mempermudah pelaksanaan pembelajaran yang kreatif dan menyenangkan.

\section{METODE PENELITIAN}

Jenis penelitian yang duginakan dalam penelitian ini yaitu penelitian kualitatif. Moleong (1991:23) menyatakan bahwa pendekatan kualittaif sebagai prosedur penelitian yang menghasilkan data deskriptif berupa kata-kata tertulis atau lisan dari orang-orang dan perilaku yang diamati.Instrumen utama dalam enelitian ini adalah peneliti sendiri. Kemampuan pengamatan peneliti untuk memahami focus penelitian secara mendalam dibutuhkan dalam rangka menemukan data yang optimal dan kredibel. Lokasi penelitian ini dilakukan di Sekolah Dasar Zainul Hasan Genggong Probolinggo.

Data penelitian yang dikumpulkan berupa informasi tentang kreativitas anak dalam pembelajaran melalui cerita bergambar. Data penelitian yang dikumpulkan dari berbagai sumber yang meliputi kepala sekolah dan guru sekolah dasar zainul hasan genggong probolinggo, dokumen atau arsip.

Metode pengumpulan data yang digunakan adalah metode observasi, wawancara dan dokumentasi. Arikunto (2007:28) menyatakan bahwa observasi adalah suatu teknik yang dilakukan dengan cara mengadakan pengamatan secara teliti dan sistematis. Kemudian, wawnacara adalah proses memperoleh keterangan untuk tujuan penelitian dengan cara Tanya jawab sambil berattap muka antara pewawancara dengan yang diwawancarai. Mulyasa (2009:69) menyatakan bahwa dokumentasi adalah instrument untuk mengumpulkan data tentang peristiwa atau kejadian masa lalu yang telah didokumentasikan. Kemudian, kegiatan dalam analisis data meliputi reduksi data, penyajian data, dan verifikasi data.

\section{HASIL PENELITIAN}

Dalam proses belajar mengajar salah satu pendukung keberhasilan belajar dan mengajar adalah metode. Bagi guru metode berfungsi untuk mempermudah penyampaian materi kepada peserta didik dan juga mempermudah peserta didik dalam memahami apa yang disampaikan guru. Sebelum melakukan penelitian, terlebih dahulu peneliti mengadakan observasi awal. Observasi awal ini adalah melakukan pengamatan dan wawancara kepada guru kelas dan juga kepala sekolah mengenai permasalahan-permasalahan daam melaksanakan pembelajaran yang berhubungan dengan kreatifitas anak.

Dari hasil observasi awal ditemukan bahwa dalam pembelajaran dengan bercerita guru tidak memaksimalkan pengggunaan media, sehinga sikap antusias dan rentang perhatian anak 
hanya sebentar. Hal ini mengakibatkan anak tidak bisa menyalurkan ide-idenya dengan bertanya, menjawab pertanyaan dan membuat tebakan sendiri tentang cerita yang disampaikan, bahkan sebagian siswa bercerita sendiri dengan temannya.

Kurangnya memaksimalkan media dalam pembelajaran membuat anak cepat jenuh dalam mengikuti kegiatan. Hal ini berdampak pada kurang optimalnya kreatifitas anak. Sebagai alternative permasalahan tersebut yang dapat digunakan dalam meningkatkan kreatifitas anak melalui cerita salah satunya adalah dengan memakai media buku cerita bergambar. Pada observasi selanjutnya, terkait penerapan cerita bergambar dalam meningkatkan kreatifitas anak yaitu sebelum kegiatan dimulai terlebih dahulu guru mempersiapkan media dan sumber media pembelajaran yakni buku cerita bergambar. Selain itu guru juga mensetting kelas dengan dibuat menjadi kelompok besar berbentuk lingkaran, menetapkan waktu pembelajaran serta membuat rencana dan langkah-lankah dalam membaca cerita.

Pada saat pembelajaran berlangsung peneliti melihat bahwa sebelum memulai cerita guru mempersiapkan terlebih dahulu media yang akan digunakan yaitu buku cerita bergambar, kemudian mengkondisikan atau mensetting kelas menjadi lingkaran besar. Lalu guru membuka pembelajaran dengan salam, doa, dan menyanyikan lagu, memeriksa daftar hadir siswa, mengkomunikasikan aturan yang harus di patuhi selama kegiatan bercerita, hal ini dilakukan agar anak lebih siap dan aktif dalam kegiatan, menyebutkan judul erita, tokoh-tokoh yang ada dalam cerita, agar anak lebih memahami karakter masing-masing tokoh, guru juga menyebutkan penerbit dan pengarang cerita, hal ini dilakukan agar anak menghargai hasil karya orang lain.

Dalam kegiatan ini guru membacanya dengan pelan, terkadang pad abagian-bagian tertentu guru memberi komentar dan sesekali meminta anak memberi komentar. Dlaam kegiatan ini guru memberi kesempatan pad aanak untuk bereksplorasi. Guru mencoba merangsang anak dengan pertanyaan-pertanyaan seperti siapa yang masih ingat apa tadi judul ceritanya ya? Siapa saja tokoh-tokoh yang ada dalam cerita, dan karakter tokoh yang ada dalam cerita. Kemudian sambil bercerita guru menunjukkan gambar kepada anak agar anak dapat melihat gambar karena dengan melihat gambar daya imajinasi dan fantasi anak dapat meningkat. Dan pada waktu bercerita posisi jari guru sellau siap untuk membuka halaman selanjutnya. Kemudian guru menutup kegiatan bercerita dengan mengulang kembali isi cerita bergambar. Terakhir guru enutup pembelajaran dengan lagu.

Berdasarkan pengamatan yang dilakukan, respon peserta didik dalam pembelajaran cerita bergambar menunjukkan perkembangan yang lebih baik, terlihat dari sebagian anak sudah 
menunjukkan kreativitasnya dengan berani bertanya dan menjawab pertanyaan, menebak dan akhirnya membuat jawaban atau tebakan sendiri seputar cerita dengan benar.

Disamping itu peneliti juga dapat melihat rentang perhatian anak bertambah selama guru menyampaikan cerita. Peneliti juga dpaat melihat anak -anak memperoleh kosakata baru yang belum pernah mereka ucapkan sebelumnya seperti lewat cerita yang disampaikan beberap siswa. Diakhir pembelajaran peneliti melakukan review, mengajukan pertanyaan seputar isi cerita seperti nama tokoh dan karakter yang dimiliki dalam setiap tokoh. Hal ini bertujuan untuk mengetahui sejauh mana pemahaman anak terhadap cerita yang disampaikan.

Dengan menciptakan suasana kelas yang menyenangkan melalui penerapan cerita bergambar ini, diharapkan anak-anak lebih mudah dalam memahami isi cerita sehingga dapat memunculkan kreativitasnya. Hasil observasi pertemuan selanjutnya, kegiatan awal dimulai dengan salam, mengisi daftar hadir, bermain tepuk dan bernyanyi dengan bergandengan tangan membentuk lingkaran, kemudian membaca doa sebelum belajar dan selanjutnya guru melakukan pembelajaran dengan buku cerita bergambar kembali. Pada pertemuan ini siswa sudah lebih tertib, antusias, dan lebih aktif dlaam melaksanakan kegiatan dari pada pembelajaran sebelumnya. Terlihat dari sebagan besar siswa sudah menunjukkan kreatifitasnya.

\section{PEMBAHASAN}

Sekolah Dasar Zainul Hasan Genggong Probolinggo merupakan salah satu lembaga pendidikan bagi anak usia dini yang berada di lingkungan pesantren Zainul Hasan Genggong Probolinggo.

Berdasrakan hasil observasi awal penerapan cerita bergambar di Sekolah Dasar Zaiul Hasan Genggong probolinggo kegiatan anak dalam bercerita masih kurang antusias, rentang perhatian sebentar, banyak yang bercerita sendiri dengan temannya, dan tidak mau bertanya, menjawab pertanyaan atau membuat tebakan seputra cerita. Hal ini disebabkan guru tidak memaksimalkan penggunaan media pembelajaran.

Solusi yang dapat digunakan dalam emningkatkan kretaivitas anak melalui cerita salah satunya adalah dengan memakai media buku bergambar. Kemudian pada kegiatan bercerita selanjtnya guru menggunkaan buku cerita bergambar sebagi media pendukung. Terkait penerapan cerita bergambar dalam meningkatkan kretaifitas anak, sebelum kegiatan dimulai yang dilakukan guru terlebih dahulu adalah (1) mempersiapkan media dan sumber pembelajaran dlaam hal ini buku cerita bergambar, (2) mensetting kelas dengan dibuat menjadi kelompok 
besar berbentuk lingkaran, (3) menetapkan waktu pembelajaran, (4) membuat rencana dan langkah-langkah dalam membahas cerita.

Selanjutnya setelah salam, membaca do'a dan mengisi daftar hadir dan mengkondisikan anak, guru memulai kegiatan bercerita dengan langkah-langkah sebagai berikut : (1) guu membaca terlebih dahulu buku yang hendak dibacakan didepan anak, (2) Membacakan cerita dengan lambat dengan kalimat ujaran yang lebih dramatic dari pada urutan biasa, (3) Pad abagian-bagian tertentu, guru berhenti sejenak untuk memberikan komentar, atau meminta anakanak memberikan komentar mereka, (4) Guru sering berhenti untuk menunjukkan gambargambar dalam buku, dan memastikan semua aak dapat melihat gambar tersebut, (5) Posisi jari selalu siap dalam posisi untuk membuka halaman selanjutnya, (6) Melakukan pembacaan sesuai rentang atensi anak dan tidak bercerita lebih dari 10 menit, (7) guru memposisikan tempat duduk ditengah agar anak bias melihat dari berbagai arah sehingga anak dapat melihat gambar secara keseluruhan, (8) Pencerita melibatkan anak dalam cerita supaya terjalin komunikasi multiarah, (9) Pencerita menyebutkan identitas buku, seperti jdul buku dan pengarang supaya anak-anak belajar menghargai karya orang lain.

Melalui penggunaan langkah-langkah atau teknik-teknik bercerita diatas anak dapat menunjukkan reaksi kreatifnya seperti mengajukan pertanyaan, menebak-nebak yang kemudian menemukan jawaban terhadap alur cerita yang mereka dengar, rentang perhatian anak terhadap cerita menjadi lebih panjang karena anak berkonsentrasi terhadpa cerita, anak juga mampu mengorganisasikan kemampuan diri karena anak belajar dari pengalaman yang menakjubkan sehingga akan membangun kepercayaan diri terhadap apa yang disampaikan.

Berdasarkan uraian diatas penulis dapat menyimpulkan bahwa dalam upaya meningkatkan kreatifitas anak melalui cerita bergambar, guru sekolah dasar zainul hasan genggong probolinggo telah menerapkan pembelajaran bercerita dengan langkah-langkah atau teknik yang baik dan sesuai dengan teori yang telah disebutkan sebelumnya. Sedangkan kreatifitas anak dapat dilihat dari reaksi kretaif yang ditandai dengan keberanian anak bertanya dan menjawab pertanyaan, perhatiannya bertambah, berani mengembangkan kreasinya, berfikir imajinatif, percaya diri dan bertambah kosakatanya.

Terdapat beberapa factor pendukung dalam kreatifitas anak di sekolah dasar Zainul Hasan Genggong Probolinggo, antara lain: 


\section{Waktu}

Anak akan menjadi kretaif jika anak mempunya sedikit waktu bebas untuk berkreasi dengan ide dan konsep yang dimilikinya. Guru memberi anak waktu untuk berfikir atau berimajinasi karema pada dasarnya kretaifitas juga memerlukan waktu untuk bereksplorasi, menuangkan ide atau gagasan dan konsep-konsep serta menccobanya dalam bentuk baru atau original.

\section{Dorongan atau motivasi}

Motivasi di berikan dalam bentuk kata-kata seperti ucapan selamat dan ucapan semangat yang dalam hal ini digunakan untuk memotivasi anak untuk menumbuhkan kepercayaan diri sehingga anak tidak malu dan takut lagi dalam mengungkapkan ide atau pendapatnya dalam proses pembelajaran.

\section{Sarana}

Sarana harus disediakan terutama sarana yang dapat mendorong anak untuk melakukan percobaan dan eksplorasi terhadap sarana tersebut. Dalam hal ini guru menyediakan media buku cerita bergambar untuk menunjang kreatifitas anak.

\section{Guru yang berkompeten}

Proses pendidikan disekolah tentunya tidak lepas dari peranan guru, jadi stimulasi yang diberikan guru juga dapat mempengaruhi perkembnagan kreatifitas anak. Guru yang berkompeten dimaksud adalah guru yang dapat menyajikan kegiatan yang menarik dan dapat memberi stidmulasi dan peluang pada anak untuk mengekspresikan ide-idenya sehingga dapat memupuk potensi kretaif pada anak didiknya.

Selain faktor pendukung, terdapat pula factor yang menghambat kreativitas anak yakni tidak percaya diri. Tidak percaya diri maksudnya adalah anak tidak berani menyampaikan ideide kreatifnya dengan bertanya dan menjawab pertanyaan seputar cerita, tidak percaya pada kemampuan yang dimilikinya, karena perasaan itulah akhirnya anak tidak bisa menunukkan kreativitasnya.

\section{KESIMPULAN}

Dalam penerapan cerita bergambar untuk meningkatkan kreatifitas anak, sebelum kegiatan dimulai guru terlebih dahulu mempersiapkan media dan sumber pembelajaran, mensetting kelas dengan dibuat menjadi kelompok besar berbentuk lingkaran, menetapkan waktu pembelajaran, dan membuat rencana serta langkah-langkah dalam bercerita. 
Dalam bercerita guru membacakan cerita dengan lambat, pada bagian-bagian tertentu guru berhenti sejenak untuk memberikan komentar dan sering berhenti menunjukkan gambargambar dalam buku, selalu siap dlaam posisi untuk membuka halaman selanjutnya, melakukan pembacaan sesuai rentang atensi anak, memposisikan tempat duduk ditengah, melibatkan anak dalam bercerita, dan menyebutkan identitas buku.

Dengan menggunakan teknik bercerita tersebut anak lebih antusias dan ikut berperan aktif dengan menunjukkan reaksi kreatifnya. Dengan demikian dapat disimpulan bahwa penerapan cerita bergambar dalam dapat meningkatkan kreatifitas anak dengan teknik-teknik yang dilakukan guru sudah baik dan efektif.

Disarankan kepada guru untuk lebih mengoptimalkan kegiatan belajar mengajar dengan menggunakan media buku cerita bergambar yang menarik, menyenangkan dan bervariasi agar dapat membuat anak berminat dan antusias terhadap proses kegiatan belajar sehingga pembelajaran dapat berhasil maksimal. Selain itu disarankan untuk menyediakan wadah dan kesempatan pada anak untuk berkreasi sesuai dengan minat dan inisiatifnya sendiri sehingga anak dapat mengekspresikan ide-idenya untuk beraktifitas. 


\section{DAFTAR PUSTAKA}

Ardianto, Tommy. 2007. Perencanaan Buku bercerita bergambar sejarah goa Selonangleng Kediri. Surabaya: Universitas Kriten Petra.

Arikunto, Suharsimi. 2007. Penelitian Tindakan Kelas. Jakarta:PT. Bumi Angkasa.

Hurlock, Elizabeth B. 1978. Perkembnagan Anak (jilid 2 edisi ke enam). Jakarta: Penerbit Erlangga

Mansur. 2007. Pendidikan Anak Usia Dini dalam islam. Yogyakarta: Pustaka Pelajar

Moleong, Lexy. 1991. Metodologi Penelitian Kualittaif. Bandung: PT. Remaja Rosdakarya.

Munandar. 2014. Pengembangan Kreatifitas Anak Berbakat. Jakarta: PT. Rineka Cipta.

Mulyasa, 2009. Praktik Penelitian Tindakan Kelas. Bandung: PT. Remaja Rosdyakarya.

Musfiroh, Tadkirotun. 2005. Bercerita untuk Anak Usia Dini. Jakarta: Departemen Pendidikan Nasional

Santi, Danar. 2009. Pendidikan Anak Usia Dini antara teori dan praktek. Jakarta: PT. Indeks

Suratno. 2005. Pengembangan Kreatifitas Anak Usia Dini. Jakarta: Departemen Pendidikan Nasional.

Rachmawati, yeni. 2010. Strategi Pengembangan Kretaifitas pada Anak Usia Taman Kanak-kanak. Jakarta: Kencana

Undang-undang RI. 2006. Sistem pendidikan nasional. Bandung: Citra Umbara. 